\title{
Glucagon-like peptide receptor agonists attenuate advanced glycation end products-induced inflammation in rat mesangial cells
}

Jui-Ting Chang ${ }^{1}$, Yao-Jen Liang ${ }^{2,3}$, Chia-Yu Hsu², Chao-Yi Chen ${ }^{3}$, Po-Jung Chen ${ }^{3}$, Yi-Feng Yang ${ }^{3}$, Yen-Lin Chen ${ }^{4,6}$, Dee Pei ${ }^{5,6}$, Jin-Biou Chang ${ }^{7}$ and Jyh-Gang Leu ${ }^{1,6^{*}}$

\begin{abstract}
Background: Hyperglycemia-induced advanced glycation end products (AGEs) and receptor for AGEs (RAGE) production play major roles in progression of diabetic nephropathy. Anti-RAGE effect of peroxisome proliferator-activated

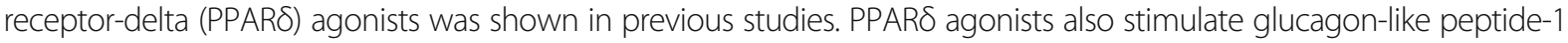
(GLP-1) secretion from human intestinal cells.

Methods: In this study, the individual and synergic anti-inflammatory effects of GLP-1 receptor (exendin-4) and PPARS (L-165,041) agonists in AGE-treated rat mesangial cells (RMC) were investigated.

Results: The results showed both exendin-4 and L-165,041 significantly attenuated AGE-induced IL-6 and TNFa production, RAGE expression, and cell death in RMC. Similar anti-inflammatory potency was seen between $0.3 \mathrm{nM}$ exendin-4 and $1 \mu \mathrm{M}$ L-165,041. Synergic effect of exendin-4 and L-165,041 was shown in inhibiting cytokines production, but not in inhibiting RAGE expression or cell death.
\end{abstract}

Conclusions: These results suggest that both GLP-1 receptor and PPAR $\delta$ agonists have anti-inflammatory effect on AGE-treated rat mesangial cells.

Keywords: Diabetic nephropathy, Glucagon-like peptide, Mesangial cell, PPAR delta, Rage

\section{Background}

Diabetic nephropathy is the leading cause of end-stage renal disease in most developed countries [1]. Large clinical trials revealed that strict control of blood glucose significantly reduced the development and progression of diabetic nephropathy in both type 1 and type 2 diabetes [2]. High serum glucose levels in diabetic patients stimulate the production of advanced glycation end products (AGEs), the transmembranous receptor for AGEs (RAGE), and various RAGE ligands in kidney cells. Ligand-induced activation of RAGE triggers numerous different signaling pathways, enhances oxidative

\footnotetext{
*Correspondence: 056111@mail.fju.edu.tw

'Division of Nephrology, Department of Internal Medicine, Shin Kong Wu Ho-Su Memorial Hospital, Taipei, Taiwan

${ }^{6} \mathrm{Fu}-J e n$ Catholic University School of Medicine, No. 510, Zhongzheng Road, Xinzhuang District, New Taipei City 24205, Taiwan

Full list of author information is available at the end of the article
}

stress, increases production of inflammatory substances, and promotes fibrosis formation [3-5]. Mesangial cells increased fibronectin production and decreased proliferation in growing on AGE-modified matrix protein. Mesangial matrix expansion is one characteristic of diabetic nephropathy [6]. The anti-RAGE and antiinflammatory therapies in mesangial cell may prevent the progression of diabetic nephropathy.

The peroxisome proliferator-activated receptor superfamily (PPARs) comprises a class of nuclear receptors with significant effects in regulating multiple cellular pathways. Activation of PPARs is through a ligand-dependent transactivation mechanism, modulating the transcriptional activity of various target genes. PPAR family comprises of three subtypes: PPAR $\alpha$, PPAR $\gamma$, and PPAR $\delta$. PPAR agonists are widely used in clinical therapy to enhance serum glucose control. The renoprotective effect of 
PPAR $\delta$ agonist on diabetic nephropathy was studied recently. A PPAR $\delta$ agonist, L-165,041, significantly decreased serum tumor necrosis factor- $\alpha$ (TNF- $\alpha$ ), interleukin-6 (IL6), and interleukin-1 (IL-1) levels, and kidney RAGE expression in streptozotocin-treated (STZ) diabetic mice [5]. Another PPAR $\delta$ agonist, GW0742, decreased urinary albumin excretion, macrophage infiltration, mesangial matrix accumulation, and expression of inflammatory mediators in kidney tissue of STZ mice [7]. PPAR $\delta$ agonists also attenuated AGE-induced pro-inflammatory cytokine production, RAGE expression, nuclear factor $-\kappa B$ pathway activation, oxidative stress, and cells apoptosis in human embryonic kidney 293 (HEK) cells [7].

Glucagon-like peptide-1 (GLP-1) is a gut incretin hormone secreted in response to food intake and augments glucose-induced insulin release from pancreatic cells [8]. GLP-1 was shown to attenuate AGE-induced RAGE mRNA expression and oxidative stress in human proximal tubular epithelial [9] and mesangial cells [10]. GLP-1 receptor agonists are being widely used in clinical treatment for type 2 diabetes. The GLP-1 receptor agonist, exendin-4, was shown to delay the progression of diabetic nephropathy in male $d b / d b$ mice [9]. Urinary albumin excretion, mesangial matrix expansion, transforming growth factor- $\beta 1$ (TGF- $\beta 1$ ) expression, and type IV collagen accumulation in mouse kidney were all significantly decreased by exendin-4. All these effects were independent to serum fasting blood glucose and glycated hemoglobin levels. Exendin- 4 also inhibits high glucose $(30 \mathrm{mmol} / \mathrm{L})$-induced TGF- $\beta 1$ and connective tissue growth factor (CTGF) expression in human mesangial cells [11].

Recently, PPAR $\delta$ agonists were found having ability to enhance glucose- and bile acid-induced GLP-1 release by intestinal $L$ cells in vitro and ex vivo in human jejunum. This phenomenon was not seen in PPAR $\delta$ deficient mice [12]. The aim of this study is to identify the renoprotective mechanisms of GLP-1 receptor agonists, and compare the potency between GLP-1 receptor and PPAR $\delta$ agonists in kidney cells.

\section{Methods}

\section{Preparation and characterization of AGEs}

AGEs were produced according to the method of Vinson and Howard with slight modifications, by incubating $10 \mathrm{mg} / \mathrm{mL}$ of fatty acid-free bovine serum albumin (BSA) with $25 \mathrm{mM}$ glyceraldehydes and $1 \mathrm{mM}$ diethylenetriaminepentaacetic acid in $0.1 \mathrm{M}$ phosphate-buffered saline ( $\mathrm{pH}$ 7.4) at $37{ }^{\circ} \mathrm{C}$ for 7 days. Unbound sugars were removed by dialysis in $10 \mathrm{mM}$ phosphate-buffered saline ( $\mathrm{pH}$ 7.4) for $24 \mathrm{~h}$. The protein content was determined by Lowry assay, using BSA as the standard. Estimation of AGE content by spectrofluorometry with excitation wavelength of $390 \mathrm{~nm}$ and emission wavelength of $450 \mathrm{~nm}$ revealed a 6.5 -fold increase in fluorescence for
AGE-BSA compared to control BSA. According to the concentration pre-test experiments, a concentration of $200 \mathrm{uM}$ of AGE was chosen for following experiments [7].

\section{Cell culture and reagents}

Rat mesangial cells (RMC) were incubated in lowglucose $(5.56 \mathrm{mM})$ media DMEM (Dulbecoo's modified eagle's medium; GIBCO ${ }^{\text {ms }} 10567$ ) with $10 \%$ fetal bovine serum at $37{ }^{\circ} \mathrm{C}$ in humidified atmosphere with $5 \% \mathrm{CO} 2$. When the mesangial cells showed aggregation growth, gradually fused and passaged them, switched to serumfree medium. The experiments were performed after 46 passages and 80\% confluence. L-165,041 and exendin are from Sigma.

\section{Measurement of tumor necrosis factor- $\alpha$ (TNF- $\alpha$ ) and interleukin-6 (IL-6)}

The cells were treated with AGE for $18 \mathrm{~h}$ with or without L-165,041 or exendin. The TNF- $\alpha$ and IL-6 levels in cell supernatants were measured by enzyme-linked immunosorbent assay (ELISA) kits (Peprotech Inc., Rocky Hill, NJ). Supernatants were diluted in the ratio of 1:30 before assay. The reaction products were measured at $450 \mathrm{~nm}$ with a microplate reader.

\section{RNA isolation and reverse transcription}

Total cellular RNA was isolated from RMC using the single step acid guanidinium thiocyanate/phenol/chloroform extraction method. For reverse transcription, $1 \mu \mathrm{g}$ of RNA was incubated with $200 \mathrm{U}$ of HiScript I reverse transcriptase (Bionovas Biotechnology, Toronto, Canada) in a buffer containing a final concentration of $20 \mathrm{mmol} / \mathrm{l}$ Tris/ $\mathrm{HCl}$ (pH 7.8), $100 \mathrm{mmol} / \mathrm{l} \mathrm{NaCl}, 0.1 \mathrm{mmol} / \mathrm{l}$ EDTA, $1 \mathrm{mmol} / \mathrm{l}$ DTT, $50 \%$ glycerol, $2.5 \mathrm{~mol} / \mathrm{l}$ poly $(\mathrm{dT})_{12-18}$ oligomer, and $0.5 \mathrm{mmol} / \mathrm{l}$ of each $\mathrm{dNTP}$ at a final volume of $20 \mu \mathrm{L}$. The reaction mixture was incubated at $45{ }^{\circ} \mathrm{C}$ for $1 \mathrm{~h}$ and then at $70{ }^{\circ} \mathrm{C}$ for 15 min to inactivate the enzyme. The produced cDNA was used to generate DNA product by polymerase chain reaction (PCR).

\section{Real-time PCR}

The cDNA had a 10-fold dilution in nuclease-free water and was used for the Smart Quant Green Master Mix (Protech Technology Enterprise Co., Taipei, Taiwan): $2 \mu \mathrm{L}$ of cDNA solution, $0.5 \mu \mathrm{mol} / \mathrm{L}$ primers, $5 \mathrm{mmol} / \mathrm{L}$ magnesium chloride, and $2 \mu \mathrm{L}$ of Master SYBRGreen in nuclease-free water with a final volume of $20 \mu \mathrm{L}$. The primers used for PCR were: RAGE: forward, 5' AAGCCCCTGGTGCCTAATGAG3', reverse, 5'CACCAATTGGACCTCCTCCA3'; GLP-1: forward, 5'CAT TCACAGGGCACATTCACC3', reverse, 5'ACCAGCCAAGCAATGAATTCCTT3'; GAPDH: forward, 5'AGACAGCCGCATCTTCTTGT3', reverse, 5'TTCCCATTC TCAGCCTTGAC3'. The initial denaturizing phase was 

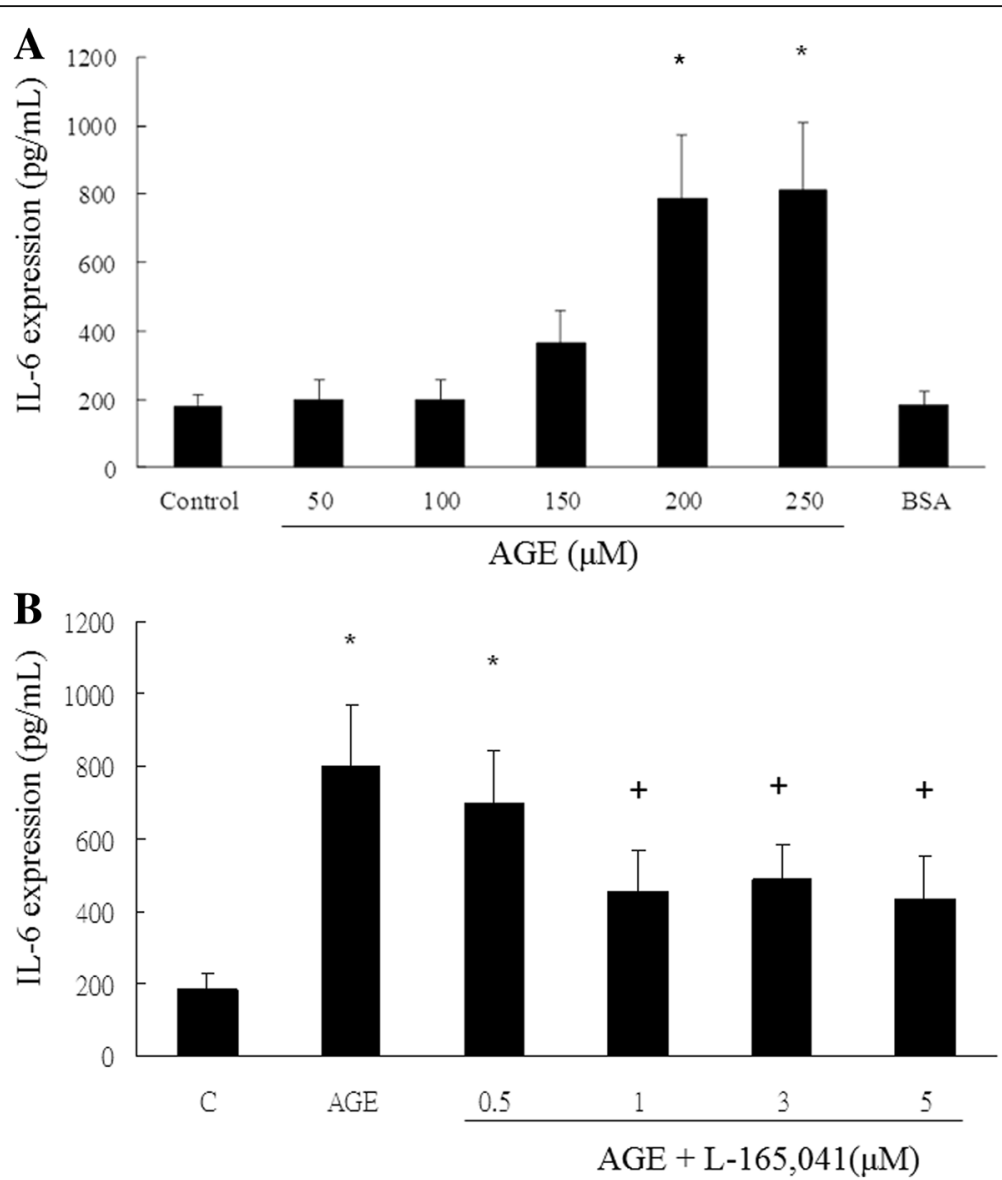

Fig. 1 L-165,041 attenuates AGE-induced interleukin-6 (IL-6) production in rat mesangial cells. ELISA was used to measure IL-6 concentrations in cell culture supernatants. a AGE stimulated IL-6 production with a dose-dependent manner. A concentration of $200 \mu \mathrm{M}$ of AGE was chosen for following experiments. b The AGE-induced IL-6 production was inhibited L-165,041 with a dose-dependent manner. A concentration of $1 \mu \mathrm{M}$ was chosen for following experiments. $(N=6) * P<0.05$ when compared to control. $+P<0.05$ when compared to AGE group

5 min at $95{ }^{\circ} \mathrm{C}$ followed by an amplification phase as detailed below: denaturation at $95^{\circ} \mathrm{C}$ for $10 \mathrm{~s}$; annealing at $55{ }^{\circ} \mathrm{C}$ for $10 \mathrm{~s}$; elongation at $72{ }^{\circ} \mathrm{C}$ for $15 \mathrm{~s}$ and detection at $79{ }^{\circ} \mathrm{C}$ for 45 cycles. Amplification, fluorescence detection, and post-processing calculation were performed using the ABI step1 apparatus. Individual PCR product was analyzed for DNA sequence to confirm the purity of the product.

\section{RNA interference}

Rat mesangial cells were transfected with 800 ng PPAR $\delta$ annealed siRNA oligonucleotide (sc-36,306) or siRNA of green fluorescent protein (GFP). PPAR $\delta$ siRNA is a pool of 3 target-specific 20-25 nt siRNA according to a computer program provided by Santa Cruz. The negative control, GFP siRNA was used: sense: 5'-GGCUACGUCCAGGAGCGCACC; antisense: 5'-UGCGCUCCUGGACGUAGCCUU (Dharmacon Inc., Lafayette, CO, USA). After overnight incubation, cells were treated with AGE, L-165,041, or exendin-4, and subjected to analysis by Western blotting.

\section{Western blot analysis}

Total protein samples were mixed with sample buffer, boiled for $5 \mathrm{~min}$, separated by 10\% SDS-PAGE under denaturing conditions, and electroblotted to nitrocellulose membranes (Amersham Pharmacia Biotech, CB, UK). The nitrocellulose membranes were blocked in blocking buffer, incubated with human anti-RAGE, anti-Nox4, anti-PKA, and anti-HO-1 (Santa Cruz Biotechnology Inc., CA) antibodies, washed, and incubated with horseradish peroxidase-conjugated secondary antibodies. Signals were visualized by enhance chemiluminescent detection.

\section{Cell viability test}

RMC were seeded onto 96-well plates in medium containing 10\% FBS and then incubated with L-165,041 or exendin, or control medium alone in $5 \% \mathrm{CO}_{2}$ for $18 \mathrm{~h}$ at $37{ }^{\circ} \mathrm{C}$. The cell viability was determined using the WST8 assay kit (Kishida Chemical Co., Ltd. JAPAN) following the manufacturer's instructions. 

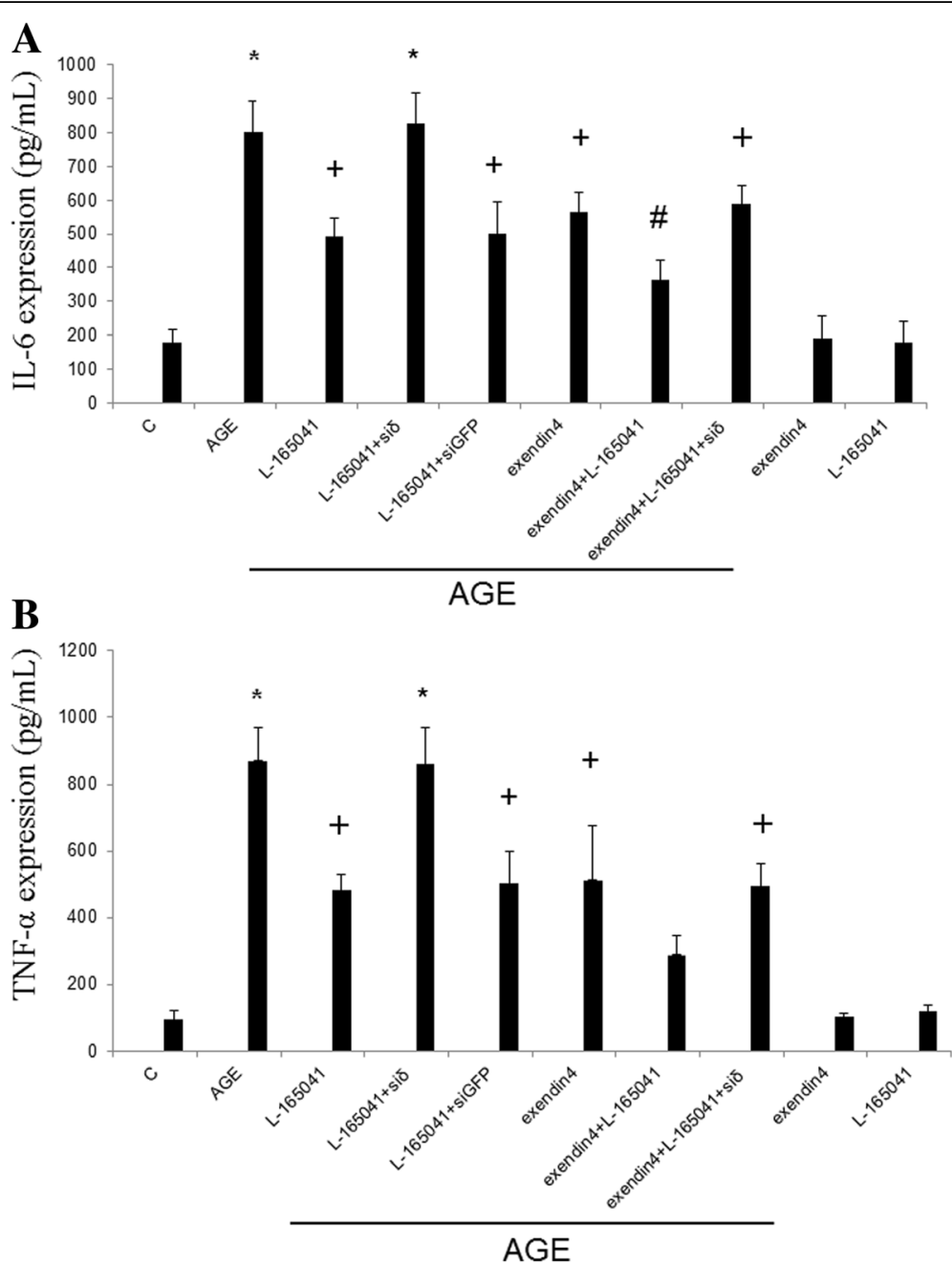

Fig. 2 Exendin-4 and L-165,041 inhibit AGE-induced IL-6 (a) and TNF-a (b) production in RMC. The inhibitory action of L-165,041 was reversed by siRNA of PPARS. L-165,041 and exendin-4 showed synergic effect in inhibiting IL- 6 and TNF-a production. L-165,041 or exendin-4 alone had no influence on IL-6 or TNF-a production in the absence of AGE. $(\mathrm{N}=6){ }^{*} \mathrm{P}<0.05$ when compared to control. $+\mathrm{P}<0.05$ when compared to AGE group. \#P $<0.05$ when compared to L-165,041 or exendin-4 group

\section{Statistical analysis}

The data were expressed as mean \pm SEM. A Tukey test was used for comparing parametric variables between the two groups, while ANOVA with repeat measurement design was used for time-course changes. Statistical significance was evaluated by Tukey test (GraphPad Software Inc., San Diego, CA). A $p$-value of less than 0.05 was considered statistically significant.

\section{Results}

PPAR $\delta$ and GLP-1 receptor agonists inhibit AGE-induced IL-6 and TNF-a production

Rat mesangial cells (RMC) were treated by serial dilutions of AGE. AGE stimulated IL-6 production in RMC with a dose-dependent manner (Fig.1a). A concentration of $200 \mu \mathrm{M}$ of AGE was chosen for following experiments. The AGE-induced IL- 6 production was inhibited by the PPAR $\delta$ agonist, L-165,041, with a dose-dependent manner (Fig.1b). A concentration of $1 \mu \mathrm{M}$ of L-165,041 was chosen for following experiments [7]. Pretreatment with L-165,041 or a GLP-1 receptor agonist, exendin-4, significantly attenuated AGE-induced IL-6 (Fig. 2a) and TNF- $\alpha$ (Fig. 2b) production in RMC. The inhibitory action of L-165,041 was reversed by siRNA of PPAR $\delta$. L-165,041 and exendin-4 showed synergic effect in inhibiting IL-6 and TNF- $\alpha$ production. L165,041 or exendin-4 alone, however, had no influence on IL- 6 or TNF- $\alpha$ production in the absence of AGE.

\section{PPARס and GLP-1 receptor agonists inhibit AGE-induced RAGE expression}

RAGE is a key factor for causing diabetic nephropathy. We examined the effect of PPAR $\delta$ and GLP-1 receptor agonists against AGE-induced RAGE upregulation. As shown in Fig. 3, AGE significantly induced RAGE 

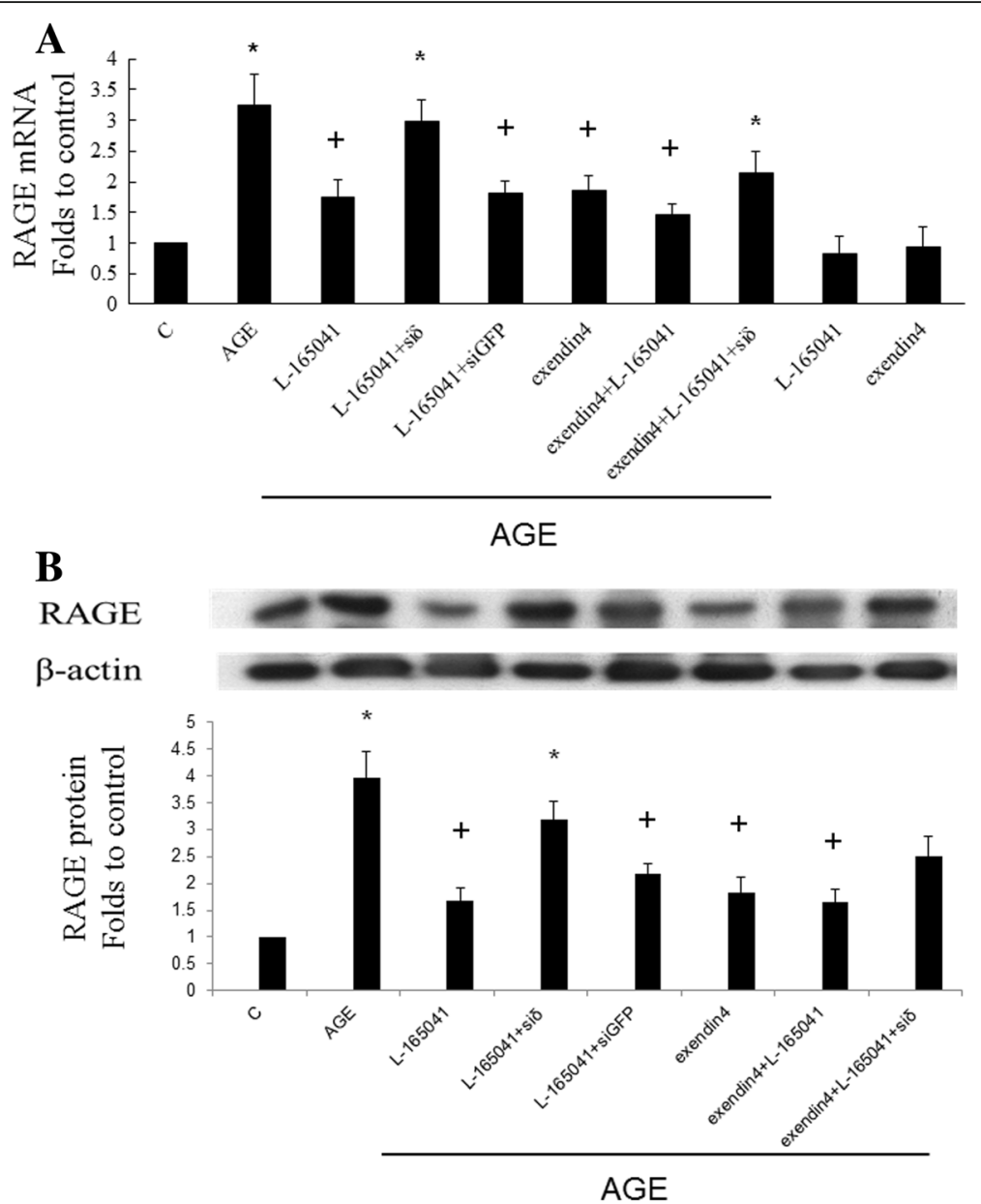

Fig. 3 Exendin-4 and L-165,041 inhibit AGE-induced RAGE mRNA (a) and protein (b) expression in RMC. AGE significantly induced RAGE mRNA and protein expression. Both exendin-4 and L-165,041 significantly attenuated AGE-induced RAGE expression. The inhibitory action of L-165,041 was reversed by siRNA of PPAR $\delta$. No synergic effect between L-165,041 and exendin-4 in inhibiting RAGE expression was noted. L-165,041 or exendin-4 alone did not change RAGE expression in the absence of AGE. $(N=6){ }^{*} \mathrm{P}<0.05$ when compared to control. $+\mathrm{P}<0.05$ when compared to AGE group

mRNA (Fig. 3a) and protein expressions (Fig. 3b) in RMC. Both L-165,041 and exendin significantly attenuated AGE-induced RAGE expression. The inhibitory action of L-165,041 was reversed by siRNA of PPAR $\delta$. No synergic effect between L-165,041 and exendin in inhibiting RAGE expression was noted. L-165,041 or exendin alone did not change RAGE expression in the absence of AGE.

The anti- oxidation effects of PPARס and GLP-1 receptor agonists

The expressions of NADPH oxidase is a key important source of ROS. After AGE treatment, Nox4 expressions were significantly increased. However, L-165,041 and/or exendin significantly decreased AGE-induced Nox4 (Fig. 4a). Furthermore, both L-165,041 and exendin treatment reversed the AGE-decreased PKA expression in mesangial cells (Fig. 4b). The level of inhibitory did not show significantly synergic effects after L-165,041 and exendin treated together. It is known that, heme oxygenase-1 (HO-1) is an anti-oxidant and anti-apoptotic substance. Exendin treatment increased the AGE-decreased HO-1 expression better than L-165,041 treatment in mesangial cells (Fig. 4b).

\section{PPARס and GLP-1 receptor agonists attenuate AGE-induced cell death}

Previous studies showed that L-165,041 attenuated high glucose-induced apoptosis in human embryonic kidney (HEK) and mesangial cells (HMC). In this study, AGE enhanced death of RMC. Both L-165,041 (Fig. 5a) and exendin (Fig.5b) significantly attenuated AGE-induced cell death. The inhibitory action of L-165,041 was reversed by siRNA of PPAR $\delta$ (Fig. 5a). No synergic effect between L-165,041 and exendin in inhibiting AGEinduced cell death was noted. L-165,041 or exendin 

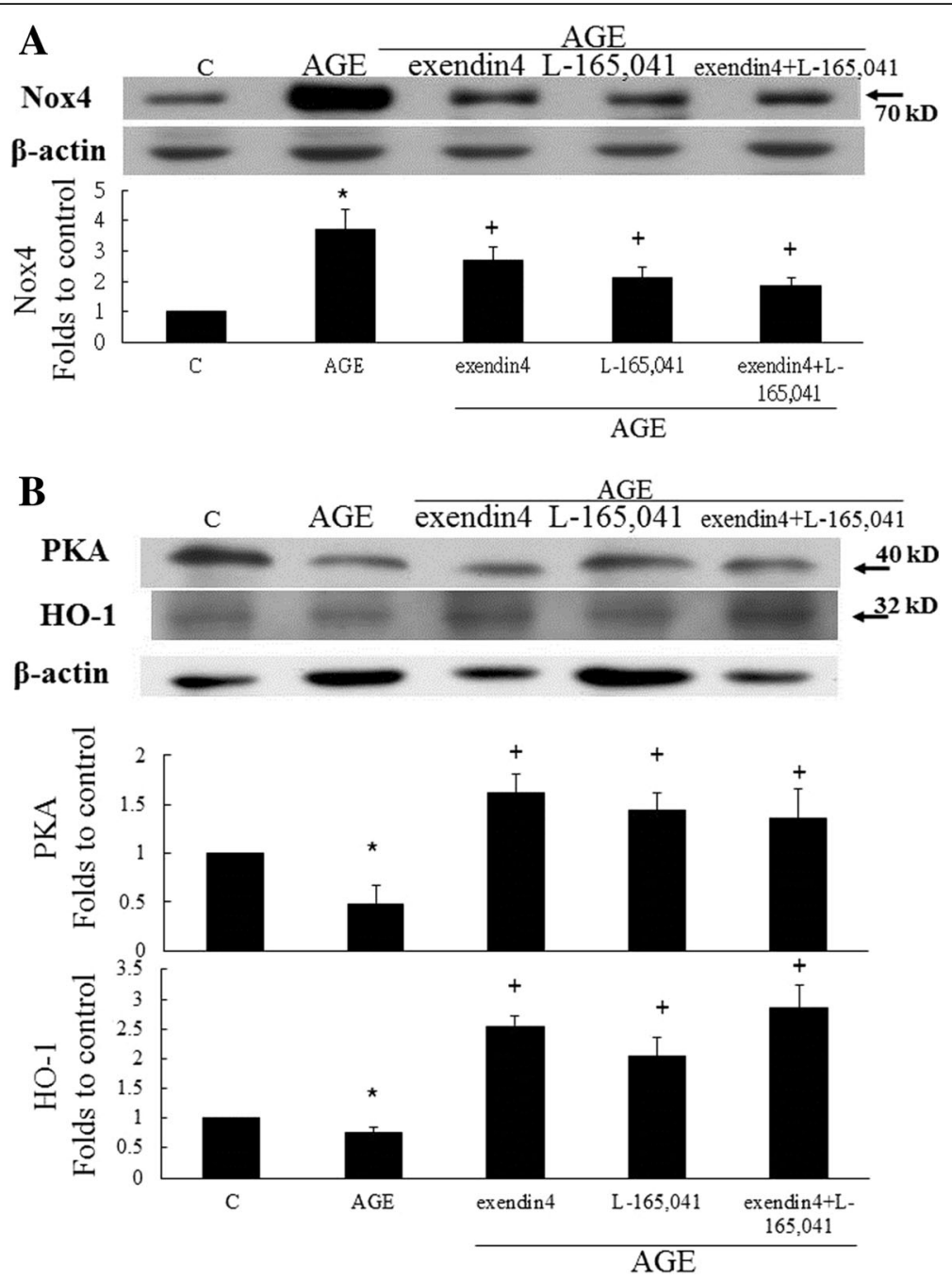

Fig. 4 The effects of L-165,041 and exendin treatment on the NAPDH oxidase, PKA and HO-1 expressions. a AGE significantly increased the Nox4 expressions. Both L-165,041 and exendin significantly decreased AGE-induced Nox4. b After L-165,041 and exendin treatment, the levels of AGE-inhibited PKA and HO-1 expression significantly increased in mesangial cells. $(\mathrm{N}=6){ }^{*} \mathrm{P}<0.05$ when compared to control. $+\mathrm{P}<0.05$ when compared to AGE group

alone showed no influence on cell survival in the absence of AGE.

\section{Discussion}

This study is the first investigation to show antiinflammatory effect of GLP-1 receptor agonists on AGEstimulated rat mesangial cells and to compare the dose potency between GLP-1 receptor and PPAR $\delta$ agonists. GLP-1 had been shown to inhibit AGE-induced inflammation in various cell lines. With a concentration of $0.3 \mathrm{nM}$, GLP-1 inhibited nonglycated bovine serum albumin (BSA)-induced RAGE expression, AGE-induced oxidative stress and cytokine expression in human mesangial cells [10], kidney proximal tubular epithelial cells [13], and umbilical vein endothelial cells [14]. In pancreatic beta cell line HIT-T 15, 10 nM GLP-1 improved AGE-induced cell death, oxidative stress, impaired insulin secretion, and RAGE expression [15]. In our study, the inhibitory of RAGE expressions by exendin-4 and L-165,041 incubation were reversed by siRNA of PPAR $\delta$ treatment. We suggest that AGE may not only induce the RAGE expressions but also PPAR $\delta$ expressions in RMC.

Few papers showed anti-inflammatory effect of GLP-1 receptor agonists on cultured cells. Exendin-4 with a concentration of $0.3 \mathrm{nM}$ was shown to inhibit high glucoseinduced transforming growth factor- $\beta 1$ (TGF- $\beta 1$ ) and CTGF in human mesangial cells [11]. In this study, $0.3 \mathrm{nM}$ exendin-4 showed similar anti-inflammatory potency on RMC to $1 \mu \mathrm{M}$ L-165,041. In previous studies, $1 \mu \mathrm{M}$ L-165,041 was able to decrease CRP-induced IL-6 expression in rat cardiomyocytes [16] and human 

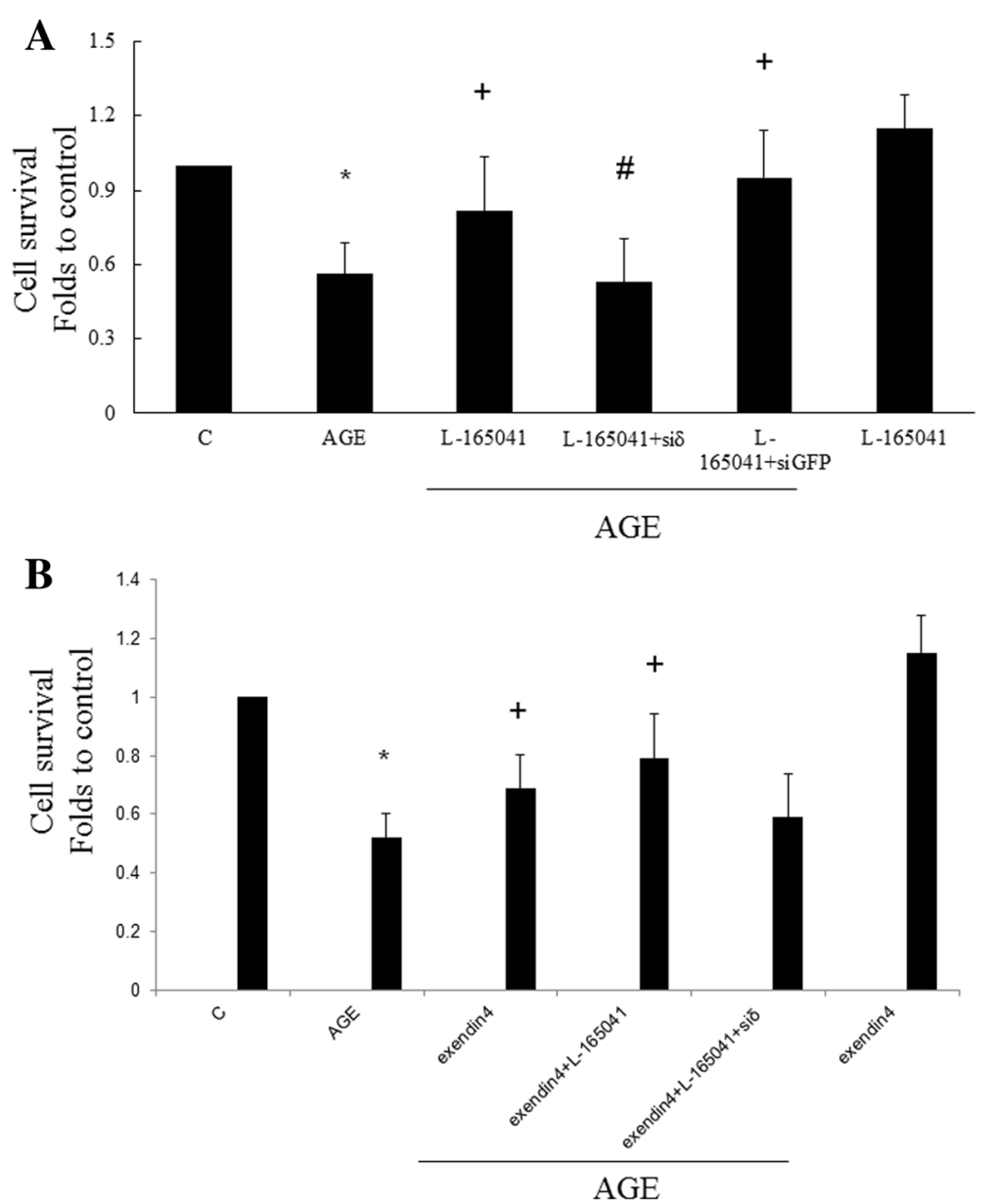

Fig. 5 Exendin-4 and L-165,041 inhibit AGE-induced cell death of RMC. AGE enhanced death of RMC. Both exendin-4 (a) and L-165,041 (b) significantly attenuated AGE-induced cell death. The effect of L-165,041 was reversed by siRNA of PPARS. No synergic effect between exendin-4 and L-165,041 in inhibiting AGE-induced cell death was noted. Exendin-4 or L-165,041 alone showed no influence on cell survival in the absence of $A G E$. ( $N=6)$ *P $<0.05$ when compared to control. $+\mathrm{P}<0.05$ when compared to AGE group

umbilical vein endothelial cells [17], and shared similar potency to another PPAR $\delta$ agonist, troglitazone $(10 \mu \mathrm{M})$, in inhibiting high glucose $(25 \mathrm{mM})$-induced inflammation and apoptosis in mesangial cells [18]. GLP-1 receptor agonists and dipeptidyl peptidase IV (DPP-4) inhibitors are being widely used in clinical treatment. These findings in dose potency are valuable for future use and development of antidiabetic agents.

The molecular mechanisms responsible for antiinflammatory effect of GLP-1 are still under investigation. Various mechanisms have been proposed [19]. Previous studies showed that GLP-1 inhibited apoptosis of insulinsecreting cells via cyclic $5^{\prime}$-adenosine monophosphate (cAMP) [20]. Cyclic AMP activates protein kinase A (PKA) and increases the expression of numerous genes via PKAmediated phosphorylation of a cAMP-responsive transcriptional factor, CREB (cAMP response element-binding protein) [21]. The cAMP-PKA-CREB axis and activated substances may be the major signal pathway responsible for anti-inflammatory effect of GLP-1. Hyperglycemia increases $\mathrm{NADPH}$ oxidase, and upregulates renal superoxide production. NADPH oxidase-induced superoxide production was shown to be reduced by cAMP and subsequent PKA [22]. Oxidative stress in vascular smooth muscle cells from spontaneously hypertensive rats was enhanced by reducing cAMP levels [23]. In this study, we demonstrated that PPAR $\delta$ agonist and GLP-1 agonist significantly decreased Nox4 expressions and increased the PKA activity. A DPP-4 inhibitor, sitagliptin, was recently shown to improve pancreatic islet vascularization through activating CREB and subsequent VEGF-A/VEGFR-2 signal pathway [24]. An analogue of cAMP, 8-Br-cAMP, induced similar effect as GLP-1 in human mesangial cells [10].

HO-1 is one of the substances activated through CAMP-PKA-CREB signal pathway [25]. GLP-1 and GLP1 receptor agonists increased $\mathrm{HO}-1$ expression and decreased oxidative stress in rat endothelial [26] and pheochromocytoma (PC12) cells [27], respectively. In a rat 
model of renal ischemia-reperfusion injury, exendin-4 significantly increased renal HO-1 expression, decreased kidney injury, caspase-3 expression, and apoptosis [28]. Our results indicated that both L-165,041 and/or exendin treatment significantly increased $\mathrm{HO}-1$ expression after AGE treatment. SREBP-1c/Caveolin-1 signaling was proved to involve in PPAR $\delta$-regulated GLP-1R expression and GLP-1R-dependent Akt/bcl-2 signaling were related to PPAR $\delta$ agonist treatment in pancreatic beta cell [29]. We suggest that PPAR $\delta$ agonist downstream signaling may correlated to GLP-1R signaling in kidney cell. Further studies are needed to identify the downstream substances of cAMP-PKA-CREB axis following GLP-1 administration and the synergic effects with PPAR $\delta$ agonists.

A number of case reports showed acute kidney injury in patients receiving exenatide, a modified peptide of GLP-1, injection for glucose control [30]. Some of these patients suffered from irreversible kidney function impairment after stopping exenatide treatment [31]. In our study, exendin-4 prevents AGE-induced cell death and no cell injury was noted. Kidney injury in clinical observation may be due to indirect mechanisms of exenatide. However, the downstream signaling and effects of GLP-1 peptide treatment in human mesangial cells should be more studied. The safety and renoprotective effect of GLP-1 receptor agonists need to be identified by largescale clinical studies.

\section{Conclusions}

In conclusion, PPAR $\delta$ and GLP-1 receptor agonists inhibit AGE-induced RAGE expressions and mesangial cell death. The renoprotective effects of PPAR $\delta$ and GLP-1 receptor agonist treatments may due to the antiinflammatory and anti-oxidative effects. The siRNA of PPAR $\delta$ reversed the exendin-decreased RAGE expressions. It is suggested that GLP-1R downstream signaling may correlate to PPAR $\delta$ activation. Further studies are necessary to identify the actual mechanism of GLP-1 administration and the synergic effects with PPAR $\delta$ agonists treatment.

\section{Abbreviations}

AGEs: Advanced glycation end products; Exendin-4: GLP-1 receptor agonist; GLP-1: Glucagon-like peptide-1; L-165,041: PPARס agonists;

PPARS: Peroxisome proliferator-activated receptor-delta; RAGE: Advanced glycation end products receptor for AGEs; RMC: Rat mesangial cells

\section{Acknowledgments}

This study was partially supported by grants from the Shin Kong Wu Ho-Su Memorial Hospital, Taipei, Taiwan. (SKH-8302-101-DR-09).

\section{Funding}

Shin Kong Wu Ho-Su Memorial Hospital, Taipei, Taiwan.(SKH-8302-101-DR-09).

\section{Availability of data and materials}

The datasets used and/or analysed during the current study available from the corresponding author on reasonable request.

\section{Authors' contributions}

JTC designed the study and wrote the manuscript. YJL designed and conceptualized the study. CYH, CYC, PJC and YFY performed study operating. YLC, DP and JBC performed the analysis and interpretation of the data. JGL performed manuscript writing and conceptualization of the study. All authors read and approved the final manuscript.

Ethics approval and consent to participate

Not applicable.

Consent for publication

Not applicable.

\section{Competing interests}

The authors declare that they have no competing interests.

\section{Publisher's Note}

Springer Nature remains neutral with regard to jurisdictional claims in published maps and institutional affiliations.

\section{Author details}

${ }^{1}$ Division of Nephrology, Department of Internal Medicine, Shin Kong Wu Ho-Su Memorial Hospital, Taipei, Taiwan. ${ }^{2}$ Department and Institute of Life Science, Fu-Jen Catholic University, New Taipei, Taiwan. ${ }^{3}$ Graduate Institute of Applied Science and Engineering, Fu-Jen Catholic University, New Taipei, Taiwan. ${ }^{4}$ Department of Pathology, Cardinal Tien Hospital, Medical School, Fu Jen Catholic University, New Taipei City, Taiwan. ${ }^{5}$ Division of Endocrinology and Metabolism, Department of Internal Medicine, Cardinal Tien Hospital, Medical School, Fu Jen Catholic University, New Taipei City, Taiwan. ${ }^{6}$ Fu-Jen Catholic University School of Medicine, No. 510, Zhongzheng Road Xinzhuang District, New Taipei City 24205, Taiwan. ${ }^{7}$ Department of Pathology, National Defense Medical Center, Division of Clinical Pathology, Tri-Service General Hospital, Taipei, Taiwan.

Received: 5 May 2017 Accepted: 9 October 2017

Published online: 24 October 2017

References

1. Ansari A, Thomas S, Goldsmith D. Assessing glycemic control in patients with diabetes and end-stage renal failure. Am J Kidney Dis. 2003;41(3):523-31.

2. Yamagishi S, Matsui T. Advanced glycation end products, oxidative stress and diabetic nephropathy. Oxid Med Cell Longev. 2010;3(2):101-8.

3. Jiao B, Wang YS, Cheng YN, Gao JJ, Zhang QZ. Valsartan attenuated oxidative stress, decreased MCP-1 and TGF-beta1 expression in glomerular mesangial and epithelial cells induced by high-glucose levels. Biosci Trends. 2011;5(4):173-81.

4. Yamagishi S. Role of advanced glycation end products (AGEs) and receptor for AGEs (RAGE) in vascular damage in diabetes. Exp Gerontol. 2011;46(4):217-24.

5. Yan SF, Ramasamy R, Schmidt AM. The RAGE axis: a fundamental mechanism signaling danger to the vulnerable vasculature. Circ Res. 2010;106(5):842-53.

6. Skolnik EY, Yang Z, Makita Z, Radoff S, Kirstein M, Vlassara H. Human and rat mesangial cell receptors for glucose-modified proteins: potential role in kidney tissue remodelling and diabetic nephropathy. J Exp Med. 1991; 174(4):931-9.

7. $\quad$ Liang YJ, Jian JH, Liu YC, Juang SJ, Shyu KG, Lai LP, Wang BW, Leu JG. Advanced glycation end products-induced apoptosis attenuated by PPARdelta activation and epigallocatechin gallate through NF-kappaB pathway in human embryonic kidney cells and human mesangial cells. Diab Metab Res Rev. 2010;26(5):406-16.

8. Meloni AR, DeYoung MB, Lowe C, Parkes DG. GLP-1 receptor activated insulin secretion from pancreatic beta-cells: mechanism and glucose dependence. Diab Obes Metab. 2013;15(1):15-27.

9. Park CW, Kim HW, Ko SH, Lim JH, Ryu GR, Chung HW, Han SW, Shin SJ, Bang BK, Breyer MD, et al. Long-term treatment of glucagon-like peptide-1 analog exendin-4 ameliorates diabetic nephropathy through improving metabolic anomalies in db/db mice. J Am Soc Nephrol. 2007;18(4):1227-38.

10. Ishibashi Y, Nishino Y, Matsui T, Takeuchi M, Yamagishi S. Glucagon-like peptide-1 suppresses advanced glycation end product-induced monocyte chemoattractant protein-1 expression in mesangial cells by reducing advanced glycation end product receptor level. Metab. 2011;60(9):1271-7. 
11. Li W, Cui M, Wei Y, Kong X, Tang L, Xu D. Inhibition of the expression of TGF-beta1 and CTGF in human mesangial cells by exendin-4, a glucagonlike peptide-1 receptor agonist. Cell Physiol Biochem. 2012;30(3):749-57.

12. Daoudi M, Hennuyer N, Borland MG, Touche V, Duhem C, Gross B, Caiazzo R, Kerr-Conte J, Pattou F, Peters JM, et al. PPARbeta/delta activation induces enteroendocrine L cell GLP-1 production. Gastroenterol. 2011;140(5):1564-74.

13. Ojima A, Ishibashi Y, Matsui T, Maeda S, Nishino Y, Takeuchi M, Fukami K, Yamagishi S. Glucagon-like peptide-1 receptor agonist inhibits asymmetric dimethylarginine generation in the kidney of streptozotocin-induced diabetic rats by blocking advanced glycation end product-induced protein arginine methyltranferase-1 expression. Am J Pathol. 2013;182(1):132-41.

14. Ishibashi Y, Matsui T, Takeuchi M, Yamagishi S. Glucagon-like peptide-1 (GLP-1) inhibits advanced glycation end product (AGE)-induced upregulation of VCAM-1 mRNA levels in endothelial cells by suppressing AGE receptor (RAGE) expression. Biochem Biophys Res Commun. 2010;391(3):1405-8.

15. Puddu A, Storace D, Durante A, Odetti P, Viviani GL. Glucagon-like peptide-1 counteracts the detrimental effects of advanced Glycation end-products in the pancreatic beta cell line HIT-T 15. Biochem Biophys Res Commun. 2010; 398(3):462-6.

16. Liang YJ, Chen CY, Juang SJ, Lai LP, Shyu KG, Wang BW, Liu SY, Leu JG. Peroxisome proliferator-activated receptor delta agonists attenuated the Creactive protein-induced pro-inflammation in cardiomyocytes and $\mathrm{H} 9 \mathrm{c} 2$ cardiomyoblasts. Eur J Pharmacol. 2010;643(1):84-92.

17. Liang YJ, Liu YC, Chen CY, Lai LP, Shyu KG, Juang SJ, Wang BW, Leu JG. Comparison of PPARdelta and PPARgamma in inhibiting the pro-inflammatory effects of C-reactive protein in endothelial cells. Int J Cardiol. 2010;143(3):361-7.

18. Liang YJ, Jian JH, Chen CY, Hsu CY, Shih CY, Leu JG. L-165,041, troglitazone and their combination treatment to attenuate high glucose-induced receptor for advanced glycation end products (RAGE) expression. Eur J Pharmacol. 2013;715(1-3):33-8.

19. Fujita H, Morii T, Fujishima H, Sato T, Shimizu T, Hosoba M, Tsukiyama K, Narita T, Takahashi T, Drucker DJ, et al. The protective roles of GLP-1R signaling in diabetic nephropathy: possible mechanism and therapeutic potential. Kidney Int. 2014;85(3):579-89.

20. Hui H, Nourparvar A, Zhao X, Perfetti R. Glucagon-like peptide-1 inhibits apoptosis of insulin-secreting cells via a cyclic 5'-adenosine monophosphate-dependent protein kinase A- and a phosphatidylinositol 3kinase-dependent pathway. Endocrinol. 2003;144(4):1444-55.

21. Gonzalez GA, Montminy MR. Cyclic AMP stimulates somatostatin gene transcription by phosphorylation of CREB at serine 133. Cell. 1989;59(4):675-80.

22. Kim JS, Diebold BA, Babior BM, Knaus UG, Bokoch GM. Regulation of Nox1 activity via protein kinase A-mediated phosphorylation of NoxA1 and 14-3-3 binding. J Biol Chem. 2007;282(48):34787-800.

23. Saha S, Li Y, Anand-Srivastava MB. Reduced levels of cyclic AMP contribute to the enhanced oxidative stress in vascular smooth muscle cells from spontaneously hypertensive rats. Can J Physiol Pharmacol. 2008;86(4):190-8.

24. Samikannu B, Chen C, Lingwal N, Padmasekar M, Engel FB, Linn T. Dipeptidyl peptidase IV inhibition activates CREB and improves islet Vascularization through VEGF-ANEGFR-2 signaling pathway. PLoS One. 2013;8(12):e82639.

25. Kronke G, Bochkov VN, Huber J, Gruber F, Bluml S, Furnkranz A, Kadl A, Binder BR, Leitinger N. Oxidized phospholipids induce expression of human heme oxygenase-1 involving activation of CAMP-responsive elementbinding protein. J Biol Chem. 2003;278(51):51006-14.

26. Oeseburg $H$, de Boer RA, Buikema $H$, van der Harst $P$, van Gilst WH, Sillje $\mathrm{HH}$. Glucagon-like peptide 1 prevents reactive oxygen species-induced endothelial cell senescence through the activation of protein kinase a. Arterioscler Thromb Vasc Biol. 2010;30(7):1407-14.

27. Yin $F$, Liu JH, Zheng XX, Guo LX. GLP-1 receptor plays a critical role in geniposide-induced expression of heme oxygenase-1 in PC12 cells. Acta Pharmacol Sin. 2010;31(5):540-5.

28. Yang $H$, Li H, Wang Z, Shi Y, Jiang G, Zeng F. Exendin-4 ameliorates renal ischemia-reperfusion injury in the rat. J Surg Res. 2013;185(2):825-32.

29. Yang Y, Tong Y, Gong M, Lu Y, Wang C, Zhou M, Yang Q, Mao T, Tong N. Activation of PPARbeta/delta protects pancreatic beta cells from palmitateinduced apoptosis by upregulating the expression of GLP-1 receptor. Cell Signal. 2014;26(2):268-78.

30. Ferrer-Garcia JC, Martinez-Chanza N, Tolosa-Torrens M, Sanchez-Juan C. Exenatide and renal failure. Diabet Med. 2010;27(6):728-9.

31. Filippatos TD, Elisaf MS. Effects of glucagon-like peptide-1 receptor agonists on renal function. World J Diab. 2013;4(5):190-201.

\section{Submit your next manuscript to BioMed Central and we will help you at every step:}

- We accept pre-submission inquiries

- Our selector tool helps you to find the most relevant journal

- We provide round the clock customer support

- Convenient online submission

- Thorough peer review

- Inclusion in PubMed and all major indexing services

- Maximum visibility for your research

Submit your manuscript at www.biomedcentral.com/submit 